\title{
Phytotoxic effects of CdTe quantum dots on root meristems of Allium cepa $\mathrm{L}$.
}

\author{
Oleksandr Smirnov ${ }^{1,2, 凶}$, Mariia Kovalenko ${ }^{1}$, Leila-Anastasiia Karpets ${ }^{1,2}$, Volodymyr
} Dzhagan $^{3,4}$, Olga Kapush ${ }^{3}$, Veronika Dzhagan ${ }^{1}$, Yevheniia Konotop ${ }^{1}$, Nataliya Taran ${ }^{1}$

${ }^{1}$ Department of Plant Biology, Educational and Scientific Centre "Institute of Biology and Medicine”, Taras Shevchenko National University of Kyiv, 64/13 Volodymyrska str., Kyiv 01601, Ukraine

${ }^{2}$ Institute of Plant Physiology and Genetics, National Academy of Sciences of Ukraine, 31/17, Vasylkivska st., Kyiv, 03022, Ukraine

${ }^{3}$ V. Lashkaryov Institute of Semiconductors Physics, National Academy of Sciences of Ukraine, 41, Pr. Nauki, Kyiv 03028, Ukraine

${ }^{4}$ Physics Department, Taras Shevchenko National University of Kyiv, 64/13 Volodymyrska str., Kyiv 01601, Ukraine $\triangle$ Corresponding author: plantaphys@gmail.com

\section{Article info}

\section{Article history:}

Received: $3^{\text {rd }}$ March 2021

Accepted: $25^{\text {th }}$ May 2021

\section{Keywords:}

Allium-test

CdTe quantum dots

Cell viability

Cytotoxicity

Mitotic index

Tolerance index

\begin{abstract}
The effect of solutions of cadmium telluride quantum dots (CdTe QD) as powerful cytotoxic effectors was investigated using a standard Allium cepa L. test system. The diameters of synthesized CdTe QD derived from the optical data varied within 3-4 $\mathrm{nm}$. Toxicity of experimental solutions of CdTe QD at the organism level were evaluated by measuring biomass growth of onion roots and cytotoxic influence was estimated based on proliferative activity of root meristem cells. All of CdTe QD experimental solutions in concentration $10 \mu \mathrm{M}$ significantly inhibited the growth of Allium cepa L. roots, proliferative activity, and total dehydrogenase activity. Relation between the QDs size and their phytotoxicity was not found. However, the highest inhibiting impact was for QDs solution with a nanocrystals size of $3.5 \mathrm{~nm}$. Their ability to penetrate into cells and interact with their intracellular components may cause inhibiting mitosis without fixed clastogenic and aneugenic effects. Solutions of CdTe QD at a given concentration can be considered as potent cytostatic agents for plant cells with antimitotic properties.
\end{abstract}

(C) University of SS. Cyril and Methodius in Trnava

\section{Introduction}

The extraordinary properties of semiconductor quantum dots (QDs) have resulted in their widespread application in various fields, from light-emitting and photovoltaic to chemical sensing and biomedical applications (Kargozar et al. 2020; Shu et al. 2020; Wang et al. 2020). QDs of Cdbased II-VI compounds, such as CdS, CdSe, CdTe, are the most developed and understood in terms of both the synthesis and optical properties (Yadav et al. 2020). Their bright (with photoluminescence quantum yield up to $90 \%$ ) coloured emission can be tuned over the whole visible spectrum by varying the QD size or/and composition (i.e. forming allow QDs, e.g. $\mathrm{CdSe}_{\mathrm{x}} \mathrm{Te}_{1-\mathrm{x}}$ ). However, the toxicity of QDs remains a concern and delays their commercialization (Jang et al. 2018).

An efficient way to reduce the Cd toxicity and simultaneously boost their optical properties is covering QD with a shell of more environmentally 
friendly material, e.g. ZnS, additionally stabilized by bio-compatible polymers (Raevskaya et al. 2007). The most recent trend in making fluorescent QDs more bio-friendly is synthesizing compounds not containing very toxic metals $(\mathrm{Cd}, \mathrm{Hg}$, or $\mathrm{Pb})$, for instance Ag-In-S (Raevskaya et al. 2018), CuIn-Se (Lox et al. 2018) or Cu-Zn-Sn-S (Stroyuk et al. 2018). The latter materials allow tuning of the light absorption and photoluminescence (PL) in the visible and near IR spectral ranges, while $\mathrm{ZnO}$ QDs are a good alternative for the UV range (Panasiuk et al. 2014). Unfortunately, an inherent drawback of all the above Cd-free QDs is the large spectral width of the PL band, $100-200 \mathrm{~nm}$, which does not allow as fine color tunability as in the case of Cd-based QDs. Moreover, recent studies show toxicity also of QDs consisting of rather non-toxic elements (Kays et al. 2020). Therefore, intense research of II-VI QDs with advanced optical properties continues (Yeshchenko et al. 2020), currently focused mostly on developing various functionalization of the NC surface and reducing toxicity (Borovaya et al. 2016; Filali et al. 2019; Garmanchuk et al. 2019; Lima et al. 2019). Of special interest are water-soluble QDs synthesized directly in aqueous solutions using bio-compatible stabilizers (ligands) (Raievska et al. 2020).

Better understanding of the behaviour of QDs in various biological environments is needed, including their impact on human health, plants, etc. Since the possibility of accumulation, uptake, and trophic transfer is long been known for $\mathrm{Cd}$ ions (Bardáčová et al. 2017), allocation of Cd-based QDs has also been studied (Hu et al. 2010; Majumdar et al. 2019; Sun et al. 2021).

From the second half of the $20^{\text {th }}$ century in ecotoxicological research, the Allium-test using various colorants is extensively used for toxicity investigation of various environmental pollutants due to its low cost and high sensitivity (Fiskesjö, 1997; Leme and Marin-Morales 2009). Studies on the effects of $\mathrm{Cd}$ ions using Allium-test have shown toxicity on macroscopic - growth responses and microscopic levels - decreasing of proliferative activity of root meristems with various clastogenic and aneugenic effects (Seth et al. 2008; Zou et al. 2012; Arya and Mukherjee 2014).

Previously in our investigation, Allium-test has also been used for the assessment of toxic impact of stabilized and non-stabilized nanoparticles of essential or biocide metals and their oxides, e.g. $\mathrm{Cu}, \mathrm{C}_{2} \mathrm{O}, \mathrm{Cu}_{2} \mathrm{O}, \mathrm{Fe}, \mathrm{Fe}_{2} \mathrm{O}_{3}, \mathrm{Fe}_{3} \mathrm{O}_{4}, \mathrm{Zn}, \mathrm{ZnO}, \mathrm{Mn}$, $\mathrm{Mn}_{3} \mathrm{O}_{4}, \mathrm{Mn}_{2} \mathrm{O}_{7}, \mathrm{Ag}, \mathrm{Ag}_{2} \mathrm{O}$ (Konotop et al. 2014; 2019). The aim of this work was to investigate toxicity of experimental solutions of CdTe QD at levels of individual cells and entire organism using the standard Allium cepa L. test system.

\section{Experimental}

\section{Nanomaterials}

All chemicals used were of analytical grade or of the highest purity available. Milli-Q water was used as a solvent. $\mathrm{CdI}_{2}, \mathrm{NaOH}$, and thioglycolic acid (TGA $\geq 90 \%$ ) were purchased from Himlaborreactive (Ukraine). CdTe QDs were synthesized by means of colloidal chemistry, following the protocol described by us previously (Kapush et al. 2019). Briefly, the low-temperature colloidal synthesis was performed in the reactor with complete mixing and in the presence of TGA as a stabilizer. Deionized water was used as the dispersion medium. $\mathrm{CdI}_{2}$ was dissolved in water and TGA was added under stirring, followed by adjusting the $\mathrm{pH}$ to 11 by dropwise addition of $\mathrm{NaOH}$ solution. $\mathrm{H}_{2} \mathrm{Te}$ gas was passed through the solution using argon as a carrier gas. The CdTe precursors formed at this stage were subsequently converted into CdTe QDs after heating the solution at $100{ }^{\circ} \mathrm{C}$. Within the given synthesis route (Kapush et al. 2019), the NCs of different size can be obtained by varying the magnitude of the electrical current flowing through the electrochemical cell in which the synthesis of the NCs took place. In particular, by changing the current from 0.1 to $0.5 \mathrm{~A}$, a series of samples with the average NC size of $3 \mathrm{~nm}$ to $4 \mathrm{~nm}$ could be obtained, as estimated from the photoluminescence spectra in Fig. 1.

\section{Photoluminescence}

PL spectra were measured from colloidal NC solutions in a standard $10 \times 10 \mathrm{~mm}$ quartz cuvette using Shimadzu RF-1501 fluorimeter. 


\section{Plant material and growth conditions}

The phytotoxicity of water solutions of cadmium telluride quantum dots were studied using the standard test object Allium cepa L. (Fiskesjö 1985). For each option, 10 equal onion bulbs, cv. Goliant, were cultivated on experimental solutions of $\mathrm{CdTe}$ QD for 5 days at $25^{\circ} \mathrm{C}$. Control plants grew in distilled water. Experimental solutions were prepared by dilution with distilled water 100 times to achieve concentration of $10 \mu \mathrm{M}$ of CdTe QD.

\section{Analysis of growth response, genotoxic and cytotoxic effects}

At the end of exposure time, fresh weight and length of roots per bulb were measured. Growth response was estimated according to the tolerance index (TI, \%) calculated as the ratio of the fresh length or weight of roots of the experimental group to the same parameter of the control group (Wilkins 1978).

Onion roots were fixed in Clark solution (ethanol : acetic acid $=3: 1$ ) and after maceration in $1 \mathrm{M} \mathrm{HCl}$ at the temperature $60{ }^{\circ} \mathrm{C}$ throughout 15 min were stained with $1 \%(\mathrm{w} / \mathrm{v})$ aqueous solution of toluidine blue. The temporary oppressed slides with root's tips were prepared and further analyzed under a light microscope (PrimoStar, Carl Zeiss) at 400-fold magnification.

Different phases of mitosis in cells of the root apical meristem were counted to calculate mitotic index, for evaluation of genotoxic effects of the experimental solutions. The mitotic index (MI, \%) was presented as number of cells in the state of division to the total number of cells observed $(3,000)$ (Eq. 1):

$\mathrm{MI}=(\mathrm{P}+\mathrm{M}+\mathrm{A}+\mathrm{T}) /(\mathrm{I}+\mathrm{P}+\mathrm{M}+\mathrm{A}+\mathrm{T}) \times 100 \%$

where $\mathrm{P}, \mathrm{M}, \mathrm{A}, \mathrm{T}, \mathrm{I}$ are quantity of cells in pro-, meta-, ana-, telo-, and interphase of mitosis respectively (Konotop et al. 2019).

Cytotoxicity assessment was providing by following the protocol of Majumdar et al. (2017) with 3-(4,5-dimethylthiazol-2-yl)-2,5-diphenyltetrazolium bromide (MTT) which is based on potential of dehydrogenases of living cells to reduce MTT. For cell viability $(\mathrm{CV})$ investigation,
$10 \mathrm{mg}$ of fresh root meristem was transferred to a microcentrifuge tube and $1 \mathrm{~mL}$ of $0.1 \%(\mathrm{w} / \mathrm{v})$ MTT aqueous solution was added into each tube and incubated $4 \mathrm{~h}$ in the dark. After incubation, the MTT solution was discarded and the root meristems were homogenized in $0.5 \mathrm{~mL} 2 \mathrm{~N} \mathrm{KOH}$ and $0.5 \mathrm{~mL} 99.99 \%$ DMSO solution in microcentrifuge tubes. After the color change observed in the solution, the content was centrifuged at $5000 \times \mathrm{g}$ at room temperature for 5 min. The clear supernatant was transferred to $1 \mathrm{~mL}$ spectrophotometry cuvette and the absorbance was determined at $570 \mathrm{~nm}$. The optical density (O.D.) value was calculated for $1 \mathrm{mg}$ of fresh tissue. $\mathrm{CV}$ was obtained by the formula (Eq. 2) and expressed as a percentage (\%):

$\mathrm{CV}=(\mathrm{O} . \mathrm{D}$. of control set - O.D. of CdTe QDs set/O.D. of control set) $\times 100 \%$

\section{Statistical analysis}

Each experiment was performed at least triplicate. The data were subjected to analysis of variance (ANOVA) with subsequent Student's t-test or Duncan's multiple range test. Data are expressed as means of replicates \pm standard deviation (bars) and were considered reliable at a significance level of $p<0.01$.

\section{Results and Discussion}

\section{CdTe QD solutions analysis}

The CdTe QDs used in this study were of several different sizes determined from the spectral position of the maximum of their PL emission, following the generally accepted calibration curves (Kamal et al. 2019). The PL spectra of the QDs solution are shown in Fig. 1a, while Fig. 1b shows normalized spectra, for a better visibility of the different spectral position of their maxima. The QD diameters derived from the optical data $(3-4 \mathrm{~nm})$ are attributed to the crystalline part of the QD as schematically shown in inset to the Fig. 1a.

An important parameter for biological applications and investigations using QDs is their hydrodynamic size, which includes the ligand shell and most often also the layer of solvent molecules. In our case, 
when the thioglycolic acid was used as the used as the stabilizer and water as solvent, the hydrodyna-
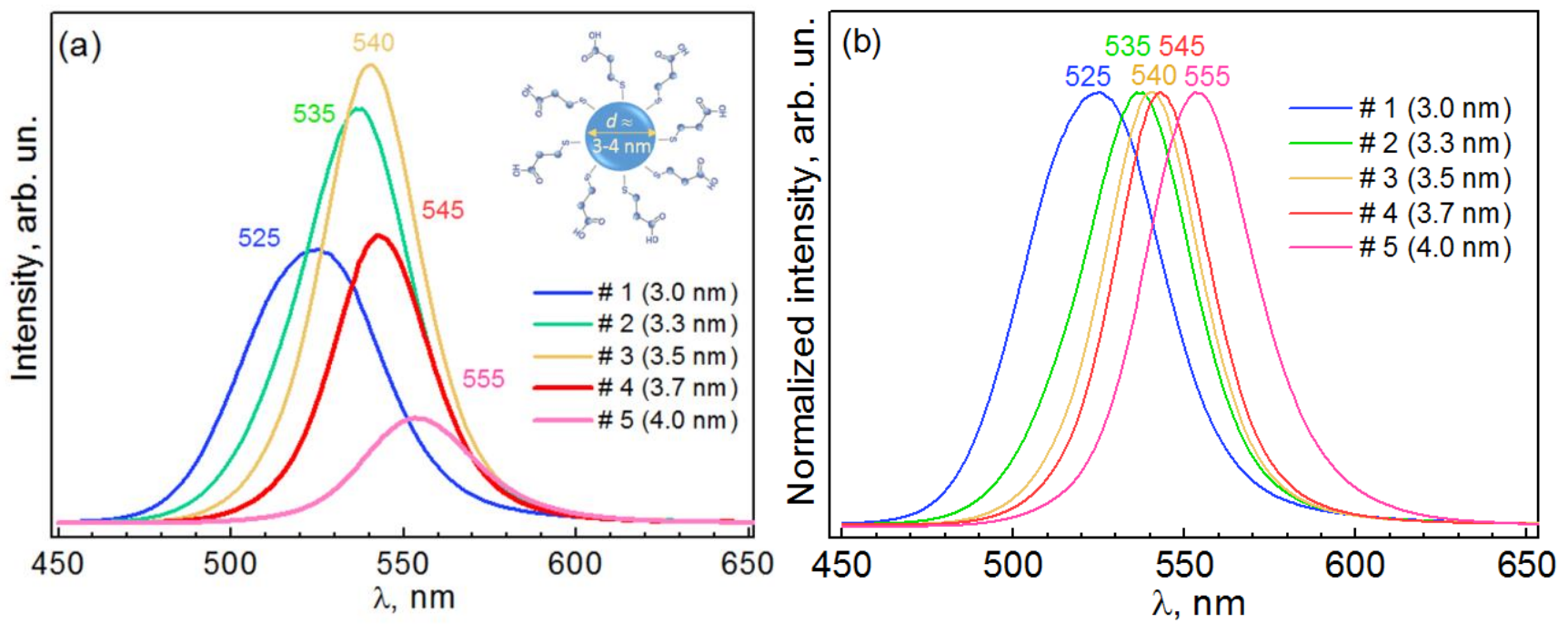

Fig. 1. Photoluminescence spectra of the CdTe QDs used in this work (measured in parental solutions). Absolute PL intensity is in (a) and (b) shows spectra with normalized intensity for better visibility of different peaks position for different samples (indicated on both figures). The inset to (a) schematically shows the QD stabilized by the ligand (TGA). Hereinafter: \#1 - 5 are numbers of QD experimental solutions.

mic diameter of the QDs was expected to be larger by not more than $1 \mathrm{~nm}$ compared to the one determined from the PL spectra, i.e. $4-5 \mathrm{~nm}$, for the series of the samples used in this work. The validity of the above estimation of the hydrodynamic QD size was confirmed by dynamic light scattering investigations of other samples pre- pared by the same synthesis approach.

\section{Growth response}

The obtained results testify that the experimental solutions of CdTe QDs vastly influence the growth of the roots of Allium cepa L. (Fig. 2).

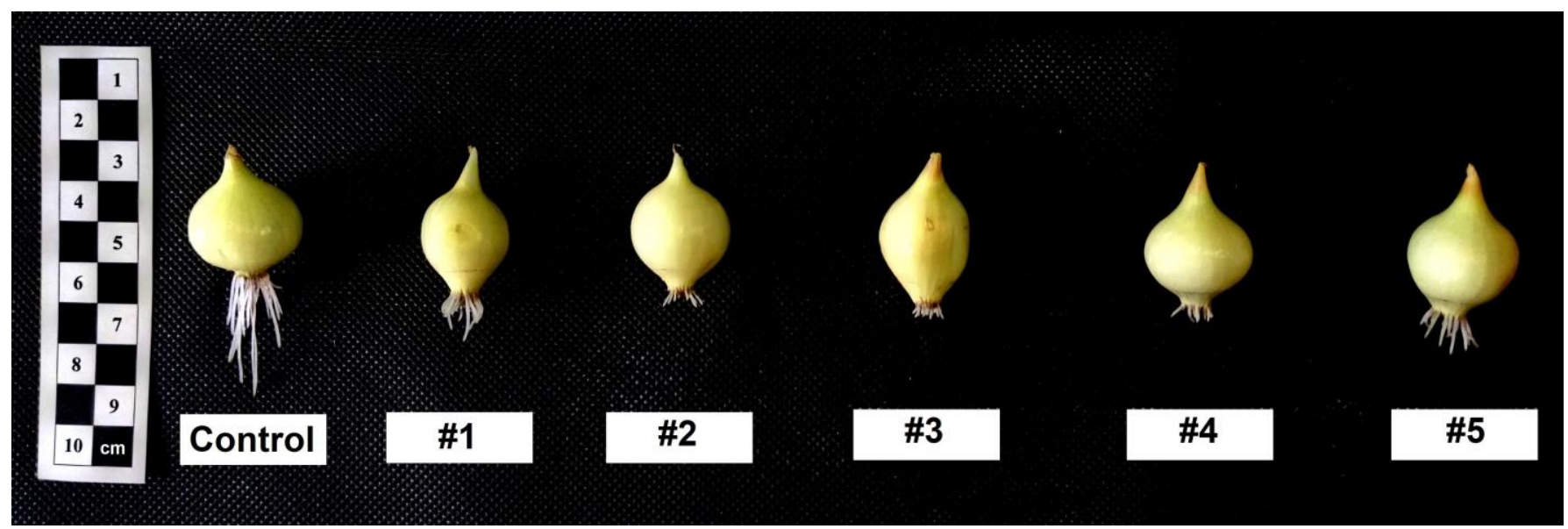

Fig. 2. Growth response of Allium cepa L. on $5^{\text {th }}$ day of cultivation on CdTe QD experimental solutions (\#1 - 5 are numbers of QD experimental solutions).

Morphometric indices of onion roots under the cultivation on experimental solutions are presented in Fig. 3. All solutions of CdTe QDs inhibited the roots growth more than by $50 \%$, index of tolerance (TI) calculated by length (Fig. 3a) showed less obvious toxicity influence of experimental solutions than TI calculated by mass (Fig 3b). TI of plants grown on the first, fourth and fifth solutions (\#1, \#4, \#5) of CdTe QDs did not differ significantly among themselves. 
The CdTe QD aqueous solutions used in this study were chosen because these Cd-based

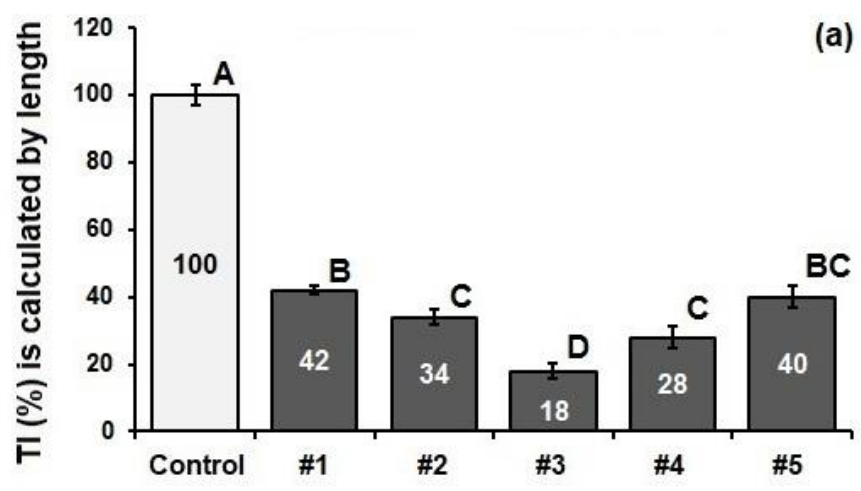

semiconductor nanocrystals in contact with aqueous media have been shown to leach $\mathrm{Cd}$ ions,

Fig. 3. Tolerance index (TI) of Allium cepa L. under cultivation on CdTe QD experimental solutions. TI (\%) is calculated by length (a) and by mass (b) of roots of onion bulbs. Hereinafter: control comprises $100 \%$; means followed by the same letters were not significantly different at $p<0.01$ according to the Duncan's multiple range test (\#1 - 5 are numbers of QD experimental solutions).

which are known for its high toxicity (El Rasafi et al. 2020). QDs are fluorescent unique semiconductor nanocomposites that are being widely developed for their strictly size-dependent physicochemical, optical and photophysical traits (Rocha et al. 2017). These traits have made QDs a suitable option for applications in various mainstream market products, including lightemitting devices such as displays of smartphones, computers and television (Hobson 2009). Furthermore, it has perspectives in biomedical research, mainly as more affective labels for multitarget simultaneous multicolor imaging of tissues and cells compared with other molecular biotechnologies and traditional fluorescent materials (Wang et al. 2020). Despite the fact that Cd-based QDs are causing agents of reactive oxygen species (ROS) in plant and animal cells and free radical damage cellular compartments, their mechanisms of phytotoxicity are still being studied (Michalet et al. 2005; Banerjee et al. 2021).

The root growth did not depend on the size of QD in the culture medium. Similarly to Modlitbová et al. (2018), bulbs of Allium cepa in control variant displayed significantly greater total length of the root system in comparison to the bulbs exposed to $10 \mu \mathrm{M}$ of all CdTe QD experimental solutions. Toxicity of CdTe QD was connected with leaching of free Cd ions from CdTe QDs (Modlitbová et al. 2018). Furthermore, these authors claim that matching of the manifestation of toxicity between $\mathrm{CdCl}_{2}$ and $\mathrm{CdTe}$ QDs showed no significant differ- rences in growth response at both tested concentrations and both terms of exposure.

\section{Cytotoxicity and genotoxicity}

To understand the causes of growth responses of plant under the impact of CdTe QDs, microscopic investigation of $A$. cepa root meristem cells was conducted (Fig. 4).

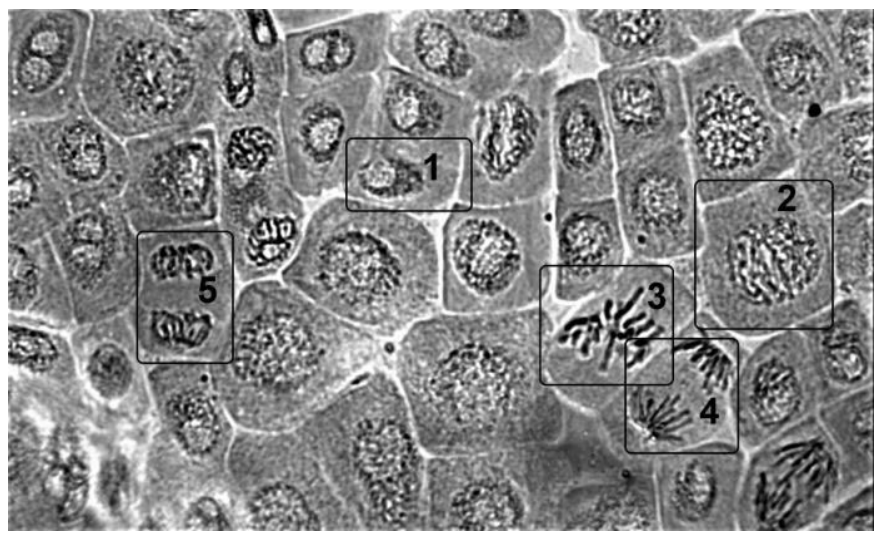

Fig. 4. Root meristem cells of control variant Allium cepa L. in the different phases of mitosis on the $5^{\text {th }}$ day of cultivation (magnification 400-fold): 1 - interphase, 2 - prophase, 3 metaphase, 4 - anaphase, 5 - telophase.

The effect of CdTe QDs solutions on the root cells division is shown in Fig. 5. The phytotoxic effect was noted for all experimental solutions - mitotic index of root meristem cells significantly differed from the control. All solutions of CdTe QDs inhibited proliferative activity of root meristems more than by $50 \%$. The most reduced proliferative 
activity of cells of root apical meristem by $78 \%$ was observed in plants grown on the third solution of CdTe QDs that accorded with TI of the same experimental option. First, second, fourth and fifth solutions (\#1, \#2, \#4, \#5) of CdTe QDs vastly inhibited the mitosis in root meristem cells by 51 $\%, 58 \%, 59 \%$ and $49 \%$ respectively (Fig. 5 ).

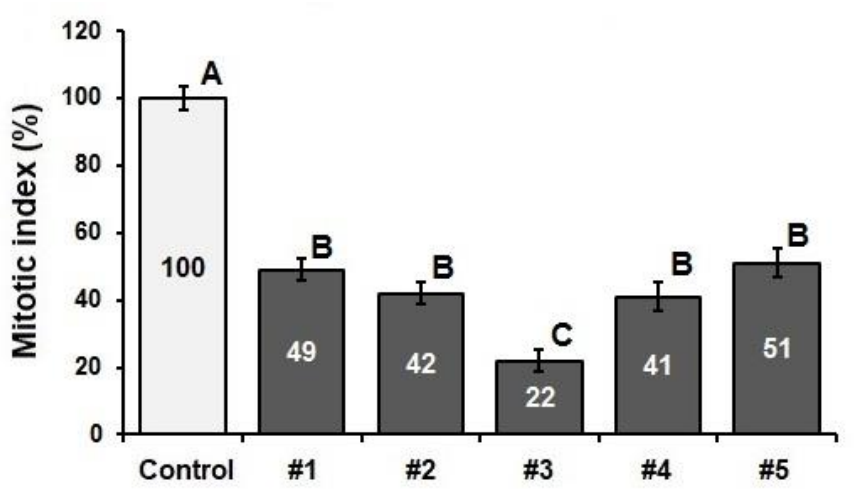

Fig. 5. Proliferative activities of cells of Allium cepa L. root meristems (vertical axis is MI, \%) under cultivation on CdTe QD experimental solutions (\#1 - 5 are numbers of QD experimental solutions).

CdTe QDs capable of releasing free cadmium ions, leading to the disruption of DNA replication, chromosomal aberrations, gene mutation and the generation of ROS (El Rasafi et al. 2020). Su et al. (2010), on the model of human embryonic kidney cells, shown the higher level of cytotoxicity of CdTe QDs than that of $\mathrm{Cd}$ ions and that the cytotoxicity was not only because of free $\mathrm{Cd}$ ions releasing. Cytotoxicity was found to be closely depended on the size of quantum dots, with smaller $(2 \mathrm{~nm})$ diameter QDs demonstrating more toxic influence than larger $(5 \mathrm{~nm})$ QDs (Lovrić et al. 2005). Chen et al. (2014) demonstrated the potential toxic effects of QDs on inducing ROS generation, pro-oxidant scavengers' activity and DNA laddering in root and shoot tissues of wheat plants.

Investigation of root cells death or meristem cells viability based on method that shown $(\mathrm{NAD}(\mathrm{P}) \mathrm{H})$ dependent dehydrogenase enzyme attendant in living cells is capable of reducing tetrazolium dye MTT. This enzyme activity takes place when the mitochondria are active therefore, the rate of reduction can directly relate to the number of viable cells. The metabolically inactive (dead) cells do not show this ability (Majumdar et al. (2017). Analysis of MTT-test results shown that first, second, fourth and fifth solutions of CdTe QDs (\#1, \#2, \#4, \#5 in Fig. 6) inhibited total dehydrogenase activity of root meristem cells approximately by $25-30 \%$.

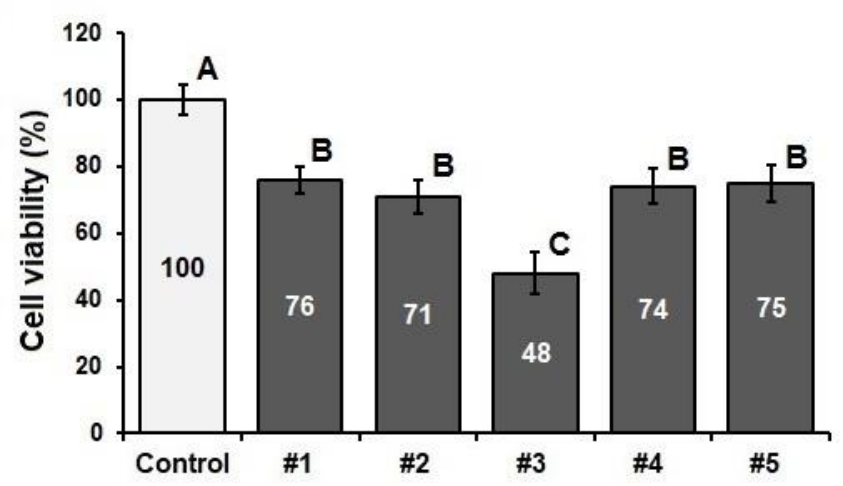

Fig. 6. The percentage of cell viability of root meristems of Allium cepa L. under cultivation on CdTe QD experimental solutions (\#1 - 5 are numbers of QD experimental solutions).

The most reduced total dehydrogenase activity of cells of root apical meristem (52\%) was observed in plants grown on the third solution of CdTe QDs (\#1) that accorded with both TI and MI traits of the same experimental option.

Since experimental solutions of CdTe QD affected growth parameters and proliferative features less than dehydrogenase activity of the root meristem, a relatively high cell viability rate could be explained by involving the CdTe QDs as cytostatic and no cytocidal effectors in the cell cycle of animal cells (Zalgevičienè et al. 2012; Garmanchuk et al. 2019). On the other hand, genotoxic influence of $\mathrm{Cd}$ ions was manifested in the form of various clastogenic and aneugenic breaches in anaphase and telophase steps of mitosis in root meristem cells of Allium cepa L. and Glycine max L. (Seth et al. 2008; Zou et al. 2012; Arya and Mukherjee 2014), disrupting the organization of cytoskeleton elements (Gzyl et al. 2015).

\section{Conclusion}

Recent review (Pagano et al. 2018) suggested that the extent to which quantum dots affect plant growth and development and their potential toxic effects may depend on QDs size, structure and stabilization characteristics. Nevertheless, even the shell presence around the QD core does not prevent the penetration and accumulation of QDs in plant 
tissues (Modlitbová et al. 2018). Due to their size, the QDs used in our investigation could be absorbed by the onion root. However, links between the QDs size and their phytotoxicity were not found. All tested solutions with nanoparticles with a size of $3-4 \mathrm{~nm}$ inhibited root growth by more than $50 \%$, as evidenced by the decrease in TI by length, TI by mass and MI. The most unfavorable conditions for onion plants were in a solution containing QDs with a size of $3.5 \mathrm{~nm}$ with maximum absorption at $540 \mathrm{~nm}$. The study did not detect genotoxic effects of QDs, although other studies have shown mitosis damages caused by $\mathrm{Cd}$ ions (Arya and Mukherjee 2014). The inhibition of plant growth could be explained by the cytostatic effect of QDs, but the mechanism remains unknown. We suggest future phytotoxicological investigation and prolonged ecotoxicology tests with QDs in environmentally relevant conditions to expand our knowledge about possible long-term effects on living organisms.

\section{Acknowledgement}

The study was supported partially by fundamental topic of Plant biology Department of Taras Shevchenko National University of Kyiv 16КФ036-07 "Solving problematic issues of diversity and stress tolerance of representatives of Ukrainian flora and mycobiota under global climate changes" (2016-2020 academic years).

\section{Conflict of interest}

Authors declare that they have no conflict of interest.

\section{References}

Arya SK, Mukherjee A (2014) Sensitivity of Allium cepa and Vicia faba towards cadmium toxicity. J. Soil Sci. Plant Nutr. 14: 447-458.

Banerjee R, Goswami P, Chakrabarti M, Chakraborty D, Mukherjee A, Mukherjee A (2021) Cadmium selenide (CdSe) quantum dots cause genotoxicity and oxidative stress in Allium cepa plants. Mutat. Res. Genet. Toxicol. Environ. Mutagen. 865: 503338.

Bardáčová M, Konotop Y, Gregorová Z, Horník M, Moravčíková J, Kraic J, Matušíková I (2017) Variable dynamics of cadmium uptake and allocation in four soybean cultivars. Nova Biotechnol. Chim. 16: 99-104.

Borovaya MN, Burlaka OM, Naumenko AP, Blume YB, Yemets AI (2016) Extracellular synthesis of luminescent CdS quantum dots using plant cell culture. Nanoscale Res. Lett. 11: 2-9.
Chen H, Gong Y, Han R (2014) Cadmium telluride quantum dots (CdTe-QDs) and enhanced ultraviolet-B (UV-B) radiation trigger antioxidant enzyme metabolism and programmed cell death in wheat seedlings. PLoS One. 9: e110400.

El Rasafi T, Oukarroum A, Haddioui A, Song H, Kwon EE, Bolan N, Tack FMG, Sebastian A, Prasad MNV, Rinklebe J (2020) Cadmium stress in plants: A critical review of the effects, mechanisms, and tolerance strategies. Crit. Rev. Environ. Sci. Technol. DOI: 10.1080/10643389.2020.1835435

Filali S, Pirot F, Miossec P (2019) Biological applications and toxicity minimization of semiconductor quantum dots. Trends Biotechnol. 38: 163-177.

Fiskesjö G (1985) The Allium-test as a standard in environmental monitoring. Hereditas. 10: 99-112.

Fiskesjö G (1997) Allium-test for screening chemicals; evaluation of cytologic parameters. In Wang W, Gorsuch JW, Hughes JS (Eds.), Plants for environmental studies. Boca Raton, CRC Lewis Publishers, New York, pp. 308.

Garmanchuk LV, Borovaya MN, Nehelia AO, Inomistova M, Khranovska NM, Tolstanova GM, Blume YaB, Yemets AI (2019) CdS quantum dots obtained by "green" synthesis: comparative analysis of toxicity and effects on the proliferative and adhesive activity of human cells. Cytol. Genet. 53: 132-142.

Gzyl J, Chmielowska-Bąk J, Przymusiński R, Gwozdz EA (2015) Cadmium affects microtubule organization and post-translational modifications of tubulin in seedlings of soybean (Glycine max L.). Front. Plant Sci. 6: 937

Hobson DW (2009) Commercialization of nanotechnology. Wiley Interdiscip. Rev. Nanomed. Nanobiotechnol. 1: 189-202.

Hu Y, Li J, Ma L, Peng Q, Feng W, Zhang L, He S, Yang F, Huang J, Li L (2010) High efficiency transport of quantum dots into plant roots with the aid of silwet L-77. Plant Physiol. Biochem. 48: 703-709.

Jang Y, Shapiro A, Horani F, Kauffmann Y, Lifshitz E (2018) Towards low-toxic colloidal Quantum dots. Z. Phys. Chem. 232: 1443-1455.

Kamal JS, Omari A, Van Hoecke K, Zhao Q, Vantomme A, Vanhaecke F, Capek RK, Hens Z (2012) Size-dependent optical properties of zinc blende cadmium telluride quantum dots. J. Phys. Chem. C.116: 5049-5054

Kapush OA, Budzulyak SI, Korbutyak DV, Vakhnyak ND, Boruk SD, Dzhagan VM, Yemets AI, Valakh MYa (2019) Influence of the dispersion medium on the properties of CdTe micro- and nanocrystals in a colloidal solution. Funct. Mater. 26: 27-34

Kargozar S, Hoseini SJ, Milan PB, Hooshmand S, Kim H-W, Mozafari M (2020) quantum dots: A review from concept to clinic. Biotechnol. J. 15: 2000117.

Kays JC, Saeboe AM, Toufanian R, Kurant DE, Dennis AM (2020) Shell-free copper indium sulfide quantum dots induce toxicity in vitro and in vivo. Nano Lett. 20: 19801991.

Konotop YO, Kovalenko MS, Ulynets VZ, Meleshko AO, Batsmanova LM, Taran NYu, (2014) Phytotoxicity of 
colloidal solutions of metal-containing nanoparticles. Cytol. Genet. 48: 99-102.

Konotop YO, Stepanchenko K, Karpets L-A, Zinchenko A, Kovalenko MS, Smirnov OE, Batsmanova LM, Taran $\mathrm{NYu}$ (2019) Phytotoxicity of colloidal solutions of stabilized and non-stabilized nanoparticles of essential metals and their oxides. Nova Biotechnol. Chim. 18: 1-9.

Leme DM, Marin-Morales MA (2009) Allium cepa test in environmental monitoring: a review on its application. Mutat. Res. 682: 71-81.

Lima MDV, De Andrade I, Cabral E, De Siqueira N (2019) Studies on toxicity of suspensions of CdTe quantum dots to Biomphalaria glabrata Mollusks. Environ. Toxicol. Chem. 38: 2128-2136.

Lovrić J, Bazzi HS, Cuie Y, Fortin GR, Winnik FM (2005) Differences in subcellular distribution and toxicity of green and red emitting CdTe quantum dots. J. Mol. Med. 83: 377-385.

Lox JFL, Dang Z, Dzhagan VM, Spittel D, Martín-García B, Moreels I (2018) Near-infrared Cu-In-Se-based colloidal nanocrystals via cation exchange. Chem. Mater. 30: 26072617.

Majumdar S, Guha T, Kundu R (2017) MTT Assay for cytotoxicity assessment in Oryza sativa root tissue. Bio101: e2620.

Majumdar S, Ma C, Villani M, Zuverza-Mena N, Pagano L, Huang Y, Zappettini A, Keller A, Marmiroli N, Dhankher OP, White J (2019). Surface coating determines the response of soybean plants to cadmium sulfide quantum dots. NanoImpact. 14: 100151.

Michalet X, Pinaud FF, Bentolila LA, Tsay JM, Doose S, Li JJ, Sundaresan G, Wu AM, Gambhir SS, Weiss S (2005) quantum dots for live cells, in vivo imaging, and diagnostics. Science. 307: 538-544.

Modlitbová P, Pořízka P, Novotný K, Drbohlavová J, Chamradová I, Farka Z, Zlámalová-Gargošová H, Romih T, Kaiser J (2018) Short-term assessment of cadmium toxicity and uptake from different types of Cd-based quantum dots in the model plant Allium cepa L. Ecotoxicol. Environ. Saf. 153: 23-31.

Pagano L, Maestri E, White JC, Marmiroli N, Marmiroli M (2018). Quantum dots exposure in plants: Minimizing the adverse response. Curr. Opin. Environ. Sci. Health. 6: 7176.

Panasiuk YV, Raevskaya OE, Stroyuk OL, Kuchmiy SY, Dzhagan VM, Hietschold M (2014) Colloidal ZnO nanocrystals in dimethylsulfoxide: a new synthesis, optical, photo- and electroluminescent properties. Nanotechnology. 25: 075601.

Raevskaya A, Rozovik O, Novikova A, Selyshchev O, Stroyuk O, Dzhagan V (2018) Luminescence and photoelectrochemical properties of size-selected aqueous copper-doped Ag-In-S quantum dots. RSC Adv. 8: 75507557.

Raevskaya AE, Stroyuk AL, Kuchmiy SY, Dzhagan VM, Valakh MY, Zahn DRT (2007) Optical study of CdS- and ZnS-passivated CdSe nanocrystals in gelatin films. J. Phys. Condens. Matter. 19: 386237.
Raievska O, Stroyuk O, Dzhagan V, Solonenko D, Zahn DRT (2020) Ultra-small aqueous glutathione-capped Ag-In-Se. RSC Advances. 10: 42178-42193.

Rocha TL, Mestre NC, Sabóia-Morais SM, Bebianno MJ (2017) Environmental behaviour and ecotoxicity of quantum dots at various trophic levels: A review. Environ. Int. 98: 1-17.

Seth CS, Misra V, Chauhan LK, Singh RR (2008) Genotoxicity of cadmium on root meristem cells of Allium cepa: cytogenetic and Comet assay approach. Ecotoxicol. Environ. Saf. 71: 711-716.

Shu Y, Lin X, Qin H, Hu Z, Jin Y, Peng X (2020) Quantum dots for display applications. Angew Chem. Int. Ed. 59: 22312-22323.

Stroyuk O, Raevskaya A, Selyshchev O, Dzhagan V, Gaponik N, Zahn DRT, Eychmüller A (2018) "Green" aqueous synthesis and optical characterization of colloidal $\mathrm{Cu}_{2} \mathrm{ZnSnS}_{4}$ nanocrystal inks. Sci. Rep. 8: 13677.

Su Y, Hu M, Fan C, He Y, Li Q (2010) The cytotoxicity of CdTe quantum dots and the relative contributions from released cadmium ions and nanoparticle properties. Biomaterials 31: 4829-4834.

Sun H, Wang M, Lei C, Li R (2021) Cell wall: An important medium regulating the aggregation of quantum dots in maize (Zea mays L.) seedlings. J. Hazard. Mater. 403: 123960.

Wang W, Liu Z, Lan X (2020) Quantum dot-based simultaneous multicolor imaging. Mol. Imaging Biol. 22: 820-831.

Wilkins DA (1978) The measurement of tolerance to edaphic factors by means of root length. New Phytol. 80: 623-633.

Yadav AN, Singh AK, Singh K (2020) Synthesis, properties, and applications of II-VI semiconductor core/shell qQuantum dots. In Tong X, Wang Z (Eds.), Core/Shell Quantum Dots, Springer Nature Switzerland AG, p. 1-28.

Yeshchenko OA, Khort PS, Kutsevol NV, Prokopets VM, Kapush O, Dzhagan V (2021) Temperature driven plasmon-exciton coupling in thermoresponsive dextrangraft-PNIPAM/Au nanoparticle/CdTe quantum dots hybrid nanosystem. Plasmonics. 75.

Zalgevičienè V, Kulvietis V, Bulotienè D, Didžiapetrienè J, Rotomskis R (2012) The effect of nanoparticles in rats during critical periods of pregnancy. Medicina (Kaunas). 48: 256-264.

Zou J, Yue J, Jiang W, Liu D (2012) Effects of cadmium stress on root tip cells and some physiological indexes in Allium cepa var. agrogarum L. Acta Biol. Cracov. S. Botanica. 54: 129-141. 